\title{
Gene expression and DNA methylation regulation of arsenic in mouse bladder tissues and in human urothelial cells
}

\author{
YEONG-CHIN JOU ${ }^{1,2^{*}}$, SHOU-CHIEH WANG ${ }^{3-5^{*}}$, YUAN-CHANG DAI ${ }^{4,6}$, SHIH-YING CHEN $^{4}$, \\ CHENG-HUANG SHEN ${ }^{1,2}$, YING-RAY LEE ${ }^{7}$, LEI-CHIN $\mathrm{CHEN}^{8}$ and YI-WEN LIU ${ }^{4}$ \\ ${ }^{1}$ Department of Urology, Ditmanson Medical Foundation Chiayi Christian Hospital, Chiayi 600; \\ ${ }^{2}$ Department of Health and Nutrition Biotechnology, Asian University, Taichung 41354; \\ ${ }^{3}$ Division of Nephrology, Department of Internal Medicine, Kuang Tien General Hospital, Taichung 437; \\ Departments of ${ }^{4}$ Microbiology, Immunology and Biopharmaceuticals, and ${ }^{5}$ Food Science, College of Life Sciences, \\ National Chiayi University; ${ }^{6}$ Department of Pathology, Ditmanson Medical Foundation Chiayi Christian Hospital; \\ ${ }^{7}$ Department of Medical Research, Ditmanson Medical Foundation Chiayi Christian Hospital, Chiayi 600; \\ ${ }^{8}$ Department of Nutrition, I-Shou University, Jiaosu, Yanchao, Kaohsiung 82445, Taiwan, R.O.C.
}

Received November 27, 2018; Accepted July 11, 2019

DOI: $10.3892 /$ or.2019.7235

\begin{abstract}
According to a report of the International Agency for Research on Cancer, arsenic and inorganic arsenic compounds are classified into Group 1 carcinogens with regard to human health. Epidemiological studies indicate that arsenic is one of the main risk factors for the development of bladder cancer. In the present study, arsenic-altered gene expression in mouse bladder tissues and in human urothelial cells was compared. In the mouse model, sodium arsenite-induced mouse urothelial hyperplasia and intracellular inclusions were present. Following DNA array analysis, four genes with differential
\end{abstract}

Correspondence to: Dr Yi-Wen Liu, Department of Microbiology, Immunology and Biopharmaceuticals, College of Life Sciences, National Chiayi University, 300 Syuefu Road, Chiayi 600, Taiwan, R.O.C.

E-mail:ywlss@mail.ncyu.edu.tw

*Contributed equally

Abbreviations: ADORA1, adenosine A1 receptor; BSP, bisulfite-sequencing PCR; CBS, cystathionine $\beta$-synthase; DEGs, differentially expressed genes; DMA, dimethylarsinous acid; DMSO, dimethyl sulfoxide; GAPDH, glyceraldehyde 3-phosphate dehydrogenase; GEO, Gene Expression Omnibus; IARC, International Agency for Research on Cancer; MALAT1, metastasis-associated lung adenocarcinoma transcript 1; MMA, monomethylarsonous acid; MSP, methylation-specific PCR; MTT, 3-(4,5-Dimethylthiazol-2-yl)-2,5-diphenyltetrazolium bromide; SEM, scanning electron microscopy; USEPA, United States Environmental Protection Agency; USP, unmethylation-specific PCR; WIF1, Wnt inhibitory factor 1

Key words: arsenic, bladder cancer, DNA CpG methylation, cell migration, WIF1 expression were selected for quantitative real-time PCR assay. The genes were the following: Cystathionine $\beta$-synthase $(C B S)$, adenosine A1 receptor (ADORAI), metastasis-associated lung adenocarcinoma transcript 1 (MALAT1) and Wnt inhibitory factor 1 (Wifl). The results indicated a significant increase in the levels of $C b s$ and Adoral. The analysis of the DNA CpG methylation levels of the mouse $C b s$ and Adoral genes revealed no significant change. In contrast to these observations, the four genes were further analyzed in the human normal urothelial cell line SV-HUC1. The data indicated that WIF1 gene expression was decreased by sodium arsenite, whereas this was not noted for $C B S, M A L A T 1$ and $A D O R A 1$. Sodium arsenite decreased mRNA and protein expression levels of the WIFl gene. In addition, the methylation levels of the WIFl gene were increased. Sodium arsenite inhibited cell proliferation and promoted cell migration as demonstrated in cell functional assays. The gene status was compared in 8 human urothelial cell lines, and WIF1 mRNA expression levels were determined to be higher, whereas DNA CpG methylation levels were lower in SV-HUC1 cells compared with those noted in the other 7 bladder cancer cell lines. In summary, the data indicated that sodium arsenite decreased WIF1 gene expression and promoted cell migration. The increased methylation levels of WIF1 DNA CpG could be a potential biomarker for bladder cancer.

\section{Introduction}

A total of 3 forms of arsenic compounds have been characterized, including inorganic arsenic, organic arsenic and arsenic gas. Inorganic arsenic is metabolized by a sequential process to organic arsenic in mammals (1). Arsenic and inorganic arsenic compounds are classified into Group 1 carcinogens for humans by the International Agency for Research on Cancer (IARC) (2). Arsenic is derived from volcanic and industrial activities and is emitted to the air, water and soil. The anthropogenic contamination of arsenic includes mining, burning of fossil fuels, smelting of non-ferrous metals, agriculture 
pesticides and timber preservative agents (2). The ingestion of contaminated water and food is the major route of arsenic exposure for the general population compared with air pollution.

The carcinogenicity of arsenic in humans is concluded by several epidemiological studies. Induction of lung cancer was reported by inhalation of arsenic occurring in copper smelters (3). Oral exposure of arsenic can cause skin $(4,5)$, bladder (6,7), lung (8) and liver cancers (9). In laboratory rodent studies, oral arsenic induced cancer at a very high dose compared with the levels of exposure in the human population (10). In male F344 rats, dimethylarsinic acid induced urothelial carcinoma at a dosage higher than $50 \mathrm{ppm}$ following 104 weeks of treatment (11). An additional study reported that dimethylarsinic acid induced urothelial carcinogenesis in rats (12) but not in mice (13). The dose of exposure used in mice was $500 \mathrm{ppm}$ and the exposure period was 2 years (13). Although tumor formation in mice was not present, treatment of C57BL/6 mice with inorganic arsenic for 6 days at $50 \mathrm{ppm}$ caused urothelial hyperplasia (14). Using scanning electronic microscopy (SEM), a previous study indicated that sodium arsenic could induce urothelial hyperproliferation, indicative of hyperplasia following 7 days of arsenic exposure at $25 \mathrm{ppm}$ (+3 oxidation state) in methyltransferase knockout mice (15). This finding indicated that arsenic induced urothelial cytotoxicity. In addition, arsenic and the carcinogen $\mathrm{N}$-butyl- $\mathrm{N}$-(4-hydroxybutyl)nitrosamine have been revealed to mutually promote mouse urothelial carcinogenesis (16). These studies indicated that the interaction of arsenic with other environmental carcinogens may be an important cause for arsenic-induced bladder cancer.

Despite the hazardous effects of arsenic in humans and laboratory animals, the underlining mechanism of arsenic-induced bladder damage has not been fully explained due to its complexity. In terms of gene regulation, several studies have been conducted using cDNA array analysis for investigating arsenic-induced changes in gene expression in vitro. For example, $E$-cadherin expression was revealed to be enhanced and integrin $\beta 3$ expression decreased by sodium arsenite (iAs $\left.{ }^{\mathrm{III}}\right)$, monomethylarsonous acid $\left(\mathrm{MMA}^{\mathrm{III}}\right)$, and dimethylarsinous acid (DMA ${ }^{\mathrm{III}}$ ) treatment in SV-HUC-1 immortalized human uroepithelial cells (17). Chronic 12-week exposure to $50 \mathrm{nM}$ of $\mathrm{MMA}^{\mathrm{III}}$ led to substantial biological and functional gene expression changes in another immortalized human uroepithelial cell line, namely UROtsa (18).

In the present study, an in vivo mouse model was initially used to analyze the global gene expression changes induced by arsenic, and the association of gene expression and DNA methylation was further assayed in certain cancer-related genes. In addition, the selected genes were further examined in human urothelial cells in vitro. The results indicated that arsenic-induced methylation inhibition of human WIFl gene, and human WIFl gene is always methylation inhibited in bladder cancer. It provides useful information that WIFl gene expression may be a biomarker for bladder cancer.

\section{Materials and methods}

Animals and arsenic treatment. Female (n=20 each) 8-week-old C57BL/6 mice were purchased from the National Laboratory
Animal Center (Taipei, Taiwan). All animals were maintained at the qualified animal care facility of The Biotechnology and Health Hall of National Chiayi University for a 1-week of adaptation. All mice were housed in polycarbonate cages, provided with food and water ad libitum and maintained on a 12 -h light-dark cycle at $22 \pm 2^{\circ} \mathrm{C}$ with $60 \pm 5 \%$ humidity. At 9 weeks of age, mice were administrated $50 \mathrm{ppm}$ arsenic ( $0.0867 \mathrm{mg} / \mathrm{ml}$ sodium arsenite, Sigma-Aldrich; Merck KGaA) (arsenic group) in drinking water or water only (control group) for 2 weeks. The drinking water was renewed weekly and mouse body weights were recorded twice weekly. The mice were monitored daily for their health condition by observing specific behaviors including squeals, decreased locomotor activity, and abnormal posture. The humane endpoint was reached when the weight loss of each mouse was $>20 \%$. At the endpoint, each mouse was placed in a transparent polycarbonate cage and sacrificed by gradual-fill $\mathrm{CO}_{2}$ exposure with a displacement rate of $20 \%$ chamber volume $/ \mathrm{min}$. When unconsciousness and breathing arrest were observed, the $\mathrm{CO}_{2}$ flow was maintained for about $1 \mathrm{~min}$. The death of each mouse was confirmed by prolonged palpation of heartbeat stop for $30 \mathrm{sec}$ (19) accompanied by no response observed to toe pinch reflex. Next, cervical dislocation was performed to assure euthanasia (20) and then the bladder was collected. The animal experiments were approved by the Institutional Animal Care and Use Committee of National Chiayi University approval no. 103040.1 and according to the guidelines of The Animal Research: Reporting in vivo Experiments, recommended by The National Centre for the Replacement, Refinement and Reduction of Animals in Research (21).

Bladder tissue collection for hematoxylin and eosin $(H \& E)$ staining. Following 2 weeks of treatment, the mice were euthanized and the bladder tissues were collected. A total of 12 bladders (6/group) were fixed in formaldehyde, dehydration and then embedded in paraffin. The embedded tissues were cut into $3-\mu \mathrm{m}$ sections on glass slides and then were stained with H\&E for histopathologic examination (empty bladder).

Bladder tissue collection for SEM examination. A total of 12 bladders (6/group) were used in this experiment. Following 2 weeks of treatment, the mice were euthanized and the bladder tissues were inflated in situ with Bouin's fixative (150-200 $\mu \mathrm{l} /$ bladder), and after being tied with string and removal, the bladders were placed in Bouin's fixative for $1 \mathrm{~h}$. Following fixation, the Bouin's-fixed bladders were cut in half longitudinally. One-half of a bladder was used for SEM examination and the other was used for $H \& E$ staining (inflated bladder).

Cell culture condition. Human urinary tract epithelial cell line SV-HUC-1 and human bladder carcinoma cell lines 5637, RT4, HT1376, T24, TSGH8301 and BFTC905 were purchased from Bioresource Collection and Research Center (BCRC), and J82 was obtained from ATCC. SV-HUC-1 was cultured in Ham's F12 medium with 7\% fetal bovine serum (FBS); RT4 and T24 were cultured in McCoy's 5a medium with 10\% FBS; J82 and HT1376 were cultured in MEM medium with 10\% FBS; 5637, TSGH8301 and BFTC905 were cultured in RPMI-1640 medium with 10\% FBS. All culture mediums 
contained $100 \mathrm{U} / \mathrm{ml}$ penicillin and $100 \mu \mathrm{g} / \mathrm{ml}$ streptomycin. Cells were inculated in a $\mathrm{CO}_{2}$ incubator at $37^{\circ} \mathrm{C}$, with $5 \% \mathrm{CO}_{2}$ and $95 \%$ filtered air.

Extraction of genomic DNA from mouse bladders and a human urinary epithelial cell line. After euthanization, the mouse bladders $(n=2$ each) were isolated and excised for exposure of the inner urothelium. After adding cell lysis buffer (10 mM Tris-Cl, pH 8.0, 1 mM EDTA, pH 8.0,0.1\% SDS) to the tube containing the excised bladder, the bladder was gently homogenized with a plastic pestle. The non-homogenized tissue was discarded and proteinase $\mathrm{K}(0.1 \mathrm{mg} / \mathrm{ml})$ was added, and then incubation followed at $55^{\circ} \mathrm{C}$ for $16 \mathrm{~h}$. DNase-free RNase $(0.02 \mathrm{mg} / \mathrm{ml})$ was added at $37^{\circ} \mathrm{C}$ for $1 \mathrm{~h}$ to remove RNA, then potassium acetate solution was added and mixed by inverting the tube. After centrifuging at $13,200 \mathrm{x}$ g, at $4^{\circ} \mathrm{C}$ for $10 \mathrm{~min}$, the clear supernatant was collected. Genomic DNA was precipitated by adding isopropanol and centrifuged at $13,200 \times \mathrm{g}$, at $4^{\circ} \mathrm{C}$ for $1 \mathrm{~min}$. The DNA pellet was washed twice by cold $70 \%$ ethanol, and then dissolved in an appropriate volume of TE buffer ( $\mathrm{pH}$ 7.6). SV-HUC-1 cells were treated with or without $0.5 \mu \mathrm{M}$ sodium arsenite for 2 and 10 weeks. After washing the cells by PBS (137 mM NaCl, $2.7 \mathrm{mM} \mathrm{KCl}$, $10 \mathrm{mM} \mathrm{Na} \mathrm{HPO}_{4}, 1.76 \mathrm{mM} \mathrm{KH_{2 }} \mathrm{PO}_{4}, \mathrm{pH} \mathrm{7.4)}$ and lysing the cells using cell lysis buffer, the genomic DNA was collected according to the same process as aforementioned.

Extraction of RNA from mouse bladders and a human urinary epithelial cell line. The mouse bladders ( $\mathrm{n}=6$ each) were isolated and sunk in RNAlater (Invitrogen; Thermo Fisher Scientific, Inc.) at $4^{\circ} \mathrm{C}$ for $24 \mathrm{~h}$. The bladders were transferred to TRIzol reagent (Invitrogen; Thermo Fisher Scientific, Inc.) and were homogenized by a plastic pestle. The non-homogenized tissue was discarded, and the total RNA was extracted according to the manufacturer's instructions. For SV-HUC-1 cells, after washing the cells by PBS and lysing cells using TRIzol reagent, the RNA was collected according to the same process as aforementioned. The concentration and purity of the RNA was measured by a NanoDrop 1000 spectrophotometer. Purity was verified using the ratio of the $\mathrm{OD}_{260} / \mathrm{OD}_{280}$ and $\mathrm{OD}_{260} / \mathrm{OD}_{230}$. For the microarray assay, the quality of the mouse total RNA was further accessed by Agilent 2100 Bioanalyzer.

Analysis of mRNA expression alternation using mouse oligonucleotide DNA microarray chip. One $\mu \mathrm{g}$ RNA was obtained from the total RNA of each mouse bladder ( 6 in the control and 6 in the arsenic group) to pool together to produce 2 mixed RNA samples (1 control and 1 arsenic group). Fluorescent aRNA targets were prepared from $1 \mu \mathrm{g}$ of the mixed RNA samples using OneArray ${ }^{\circledR}$ Amino Allyl aRNA Amplification kit (Phalanx Biotech Group) and Cy5 dye (GE Healthcare Life Sciences). Fluorescent targets were hybridized to the Mouse OneArray ${ }^{\circledR}$ (Phalanx Biotech Group) with Phalanx hybridization buffer using Phalanx Hybridization system. After $16 \mathrm{~h}$ of hybridization, non-specific binding targets were removed using saline and sodium citrate buffer. The slides were scanned using a DNA Microarray Scanner (Model G2505C; Agilent Technologies, Inc.). The Cy5 fluorescent intensities of each spot were analyzed using GenePix 4.1 software (Molecular
Devices, LLC). Each single sample was assessed at least twice in terms of technical or biological replicates with a reproducibility $>0.975$. The signal intensity of each spot was loaded into the Rosetta Resolver System ${ }^{\circledR}$ (Rosetta Biosoftware) to process the data (22). The error model of the Rosetta Resolver System ${ }^{\circledR}$ could remove both systematic and random errors from the data. The spots that were flagged to be $<0$ were filtered out. Spots that passed the criteria were normalized by $50 \%$ median scaling normalization method. The technical repeat data was tested by Pearson's correlation coefficient calculation to verify the reproducibility ( $R$ value $>0.975$ ). Normalized spot intensities were transformed to gene expression $\log _{2}$ ratios between the control and treatment groups. The fold change and $\mathrm{P}$-value for pair-wise sample comparisons were calculated to evaluate differentially expressed genes (DEGs). The criteria with $\log _{2}$ Ifold changel $\geq 0.58$ and $\mathrm{P}<0.05$ were used for further analysis. The $\log _{2} \mid$ fold changel $\geq 0.58$ is an acceptable value for a microarray study (23).

Reverse transcription-quantitative real-time polymerase chain reaction (RT-PCR) analysis. Four mouse genes, including adenosine A1 receptor (Adoral), cystathionine beta-synthase $(\mathrm{Cbs})$, metastasis associated lung adenocarcinoma transcript 1 (Malat1), and Wnt inhibitory factor 1 (Wifl), were selectively targeted. Each reaction included $20 \mathrm{ng}$ cDNA, $500 \mathrm{nM}$ forward and reverse primers, and 2X Fast SYBR-Green PCR Master mix (Applied Biosystems; Thermo Fisher Scientific, Inc.). A total of $10 \mu \mathrm{l}$ reaction volumes were used for RT-PCR with the specific primers listed as follows: Mouse Adoral forward, 5'-GAGGCGGACATCACATTCCAT-3' and reverse, 5'-AGC CACCTCACTCACCCTAGA-3'; Mouse $C b s$ forward, 5'-GCT GAACCAGACGGAGCAAA-3' and reverse, 5'-GGGCAA AGGCGAAGGAATCT-3'; Mouse Malat1 forward, 5'-AGG GTTCTAAAGGCTCTGGGTA-3' and reverse, 5'-AAG ACGAATTGGGCATAACCTGAA-3'; Mouse Wifl forward, 5'-TTTGTGGTCTTAGAATGGGGAGTG-3' and reverse, 5'-ACGCTGCTATTGGCTTTATCCG-3'. Each sample was assessed in triplicate. The Bio-Rad CFX Connect real-time PCR instrument and the Bio-Rad CFX Manager version 3.0 software (both from Bio-Rad Laboratories, Inc.) were used for the experimental setup and data analysis. The RT-PCR data of the target genes were normalized against the reference gene $G A P D H$ by using its specific primers forward, 5'-AAGGTC GGTGTGAACGGATT-3' and reverse, 5'-GTGAGTGGAGTC ATACTGGAACAT-3'.

Bisulfite conversion of genomic DNA and analysis of DNA methylation levels in mouse bladder tissue and human urinary epithelial cells. Five hundred nanograms of genomic DNA was subjected to sodium bisulfite modification using the EZ DNA methylation-Gold $^{\mathrm{TM}}$ kit (Zymo Research Corp.). Mouse DNA methylation levels were analyzed by bisulfite-sequencing PCR (BSP) method using bisulfite specific primers. The BSP primers for the mouse Adoral gene were 5'-TTTGAGTTTYGTAGG TGATTAGGGTTTGGGTTG-3' (forward) and 5'-CTAACC ACCTAAACTATCTAACCAAATATCCCC-3' (reverse), which amplified -282 to $201 \mathrm{bp}$ of the mouse Adoral gene (483 bp); for the mouse $C b s$ gene they were 5'-AAAYGAGGTTTTTTGATA TTTAGTTAGGTTGTG-3' (forward) and 5'-CRTCCAAAT ACAAAAAAAACCAAATCC-3' (reverse), which amplified 
-298 to 271 bp of the mouse $C b s$ gene (569 bp). Next, the PCR products were subcloned into the T\&A cloning vector (Yearstern Biotech). To determine the $\mathrm{CpG}$ methylation level of the $5^{\prime} \mathrm{CpG}$ island of each gene, 10 clones of each gene were randomly selected for sequencing. The BSP primers for the human WIFI gene were 5'-TAGGGGTTTTTGAGTGTTT-3' (forward) and 5'-ACCTAAATACCAAAAAACCTAC-3' (reverse), which amplified -168 to $236 \mathrm{bp}$ of the human WIF1 gene (404 bp). Then, a second round of nested methylation-specific PCR (MSP) or unmethylation-specific PCR (USP) was performed using the BSP-PCR products as templates. The MSP for the human WIFI gene were 5'-CGTTTTATTGGGCGTATCGT-3' (forward) and 5'-ACTAACGCGAACGAAATACGA-3' (reverse), $145 \mathrm{bp}$, and for the USP they were 5'-GGGTGTTTTATTGGGTGTATT GT-3' (forward) and 5'-AAAAAAACTAACACAAACAAA ATACAAAC-3' (reverse), $154 \mathrm{bp}$. The MSP and USP PCR products were analyzed by $1 \%$ agarose gel. No regular loading control such as a housekeeping gene for the MSP/USP assay was used since its aim was to determine the relative methylation status of the WIFl gene instead of the absolute expression level. A subsequent RT-PCR was applied to confirm the mRNA level of WIF1 under such methylation status with GAPDH as the loading control.

RNA expression detection of human ADORA1, CBS, MALATI and WIF1 genes in human urinary epithelial cells. Total RNA was isolated from cells. Reverse transcription (RT) was performed on $2 \mu \mathrm{g}$ of total RNA by $1.5 \mu \mathrm{M}$ random hexamer and RevertAid ${ }^{\mathrm{TM}}$ reverse transcriptase (Fermentas; Thermo Fisher Scientific, Inc.). Then, 1/20 volume of reaction mixture was used for PCR with human ADORAl-specific primers (5'-TTTGGTGACCTTGGGTGCTT-3', 5'-ACCACCATCTTG TACCGGAG-3', product size $427 \mathrm{bp}$ ); $C B S$-specific primers (5'-GTCGCTCAGGAACTTGGTCA-3', 5'-GAACCAGAC GGAGCAGACAA-3', product size 286 bp); MALAT1-specific primers (5'-TTATCCAGTGACTAAAACCAAC-3', 5'-AAA AGGAGAAATACAGAAAGAG-3', product size $443 \mathrm{bp}$ ); WIFl-specific primers (5'-CACTCGCAGATGCGTCTTTC-3', 5'-CCAACCGTCAATGTCCCTCT-3', product size $251 \mathrm{bp}$ ); and $G A P D H$-specific primers (5'-CAAGGTCATCCATGA CAACTTTG-3', 5'-GTCCACCACCCTGTTGCTGTAG-3', product size $496 \mathrm{bp}$ ). The PCR products were analyzed by $1-2 \%$ agarose gel.

Cell proliferation assay by 3-(4,5-Dimethylthiazol-2-yl)2,5-diphenyltetrazolium bromide (MTT). The number of proliferating cells was determined by a colorimetric MTT assay. After cells were treated with or without $0.5 \mu \mathrm{M}$ sodium arsenite for 14 days, the cells were seeded in 96 -well plates without sodium arsenite, then were incubated for $2 \mathrm{~h}$ (Day 0 ) and for 1-4 days. MTT was added into the medium for $2 \mathrm{~h}$, then the medium was discarded and dimethyl sulfoxide was added to dissolve the formazan product. Each well was measured by light absorbance at $490 \mathrm{~nm}$. The result was expressed as the fold to the Day 0 control group.

Cell migration analysis by Transwell. A cell migration assay was conducted using 24 -well Transwell inserts $(8 \mu \mathrm{m}$ pore PET filters; EMD Millipore). In brief, after arsenic treatment, SV-HUC-1 cells $\left(2 \times 10^{5}\right.$ cells/well) were placed in the upper chamber of the Transwell insert in serum-free medium, and then incubated for $24 \mathrm{~h}$. Medium containing 7\% FBS was placed in the lower chamber. At the end of the incubation period, the non-migrated cells were removed using a cotton swab; the migrated cells maintained in the insert filter were fixed with $4 \%$ formaldehyde (at $25^{\circ} \mathrm{C}$ for $5 \mathrm{~min}$ ) and stained with $0.5 \%$ crystal violet $\left(25^{\circ} \mathrm{C}, 5 \mathrm{~min}\right)$. In the lower surface of the filter, cells penetrated were counted and photographed under a phase-contract microscope at a magnification of $\mathrm{x} 100$. The crystal violet was dissolved by $100 \mu 1 \mathrm{DMSO} /$ insert and counted by a spectrophotometer at $580 \mathrm{~nm}$. Three independent experiments were performed.

Statistical analysis. The statistical analysis was performed using SigmaPlot version 12.5 (Systat Software, Inc.). Statistical differences were analyzed by Student's t-test and a P-value $<0.05$ was considered to indicate a statistically significant difference. Microarray data were processed using the Rosetta Resolver System ${ }^{\circledR}$, which performs unique error modeling to adjust for background noise and fractional noise. The P-value representing the probability of differentially expressed genes was thereby generated by a patented system according to a standard Gaussian distribution based on standardized variance of the intensity difference (22).

\section{Results}

Short-term treatment of high-dose sodium arsenite induces hyperplasia and dysplasia in mouse urothelium. It has been revealed that a clear morphological change in the mouse urothelium can occur following $50 \mathrm{ppm}$ of arsenic treatment for 6 days (14). Therefore, in the present study, a high-dose $(50 \mathrm{ppm})$ of arsenic treatment was used for a short-term period (14 days). The study aimed to identify the morphological changes induced by arsenic in urothelial cells and the corresponding alterations in gene expression. Following $50 \mathrm{ppm}$ of arsenic intake for 2 weeks, the mice were alive and their body weight was gradually increased (Fig. 1A). No significant difference was noted in the body weight change between the control and the arsenic-treated animal groups(Fig. 1A). This suggested that $50 \mathrm{ppm}$ of arsenic intake that was administered for a 2-week duration may not significantly affect the animal appetite or their general health condition. The exterior appearance and physical activity of the animals further indicated no noticeable difference between the control and the arsenic-treated groups. Following euthanasia, the mouse bladders were harvested for histopathological and genetic assessments. The histopathological examination (Fig. 1B and C) revealed that arsenic induced $83.3 \%$ (10/12) hyperplasia and 8.3\% (1/12) dysplasia in mouse urothelium, which represented the precancerous characteristics of the urothelium. In the hyperplastic tissue, the analysis indicated increased thickness of the urothelium for more than four layers without cellular atypia (Fig. 1C, arsenic group). In the dysplastic tissue, the analysis indicated apparent cytologic and architectural atypia of the urothelium without evident invasion. Moreover, intracellular inclusions were present within the umbrella cells of the sodium arsenite-treated mice (Fig. 1C, arrow), which acted as a detoxifying sequestration mechanism (24). Using SEM, the accumulation of round cells was observed, which further indicated urothelial hyperplasia 
A

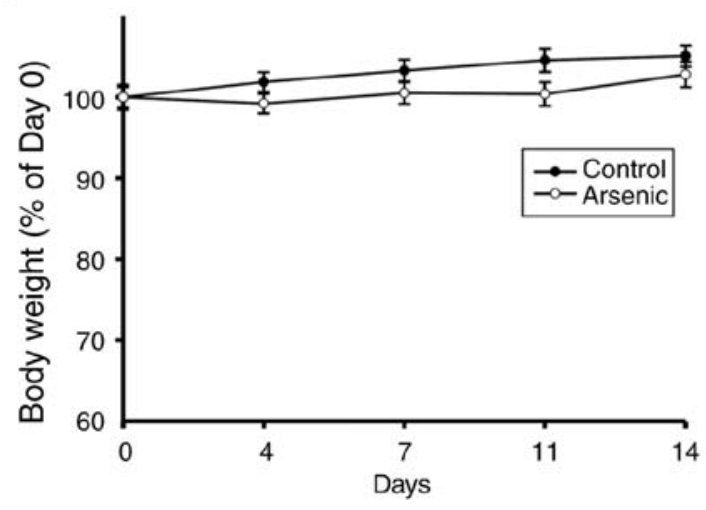

B
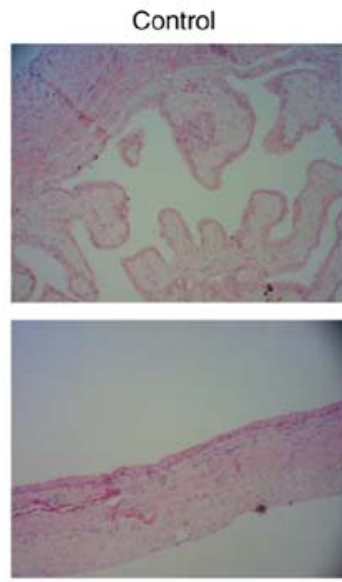

D

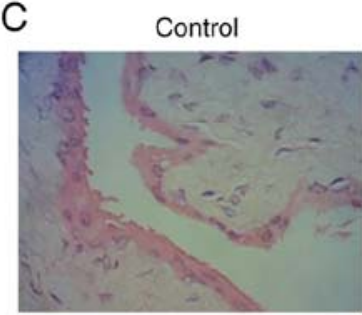

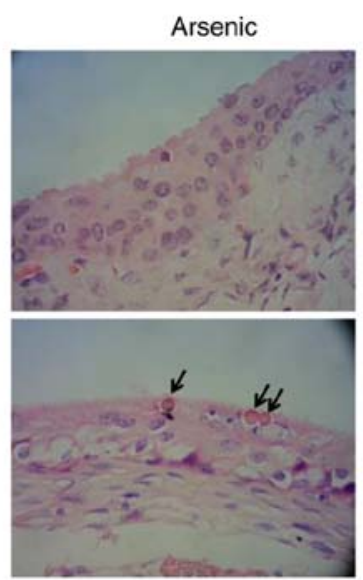
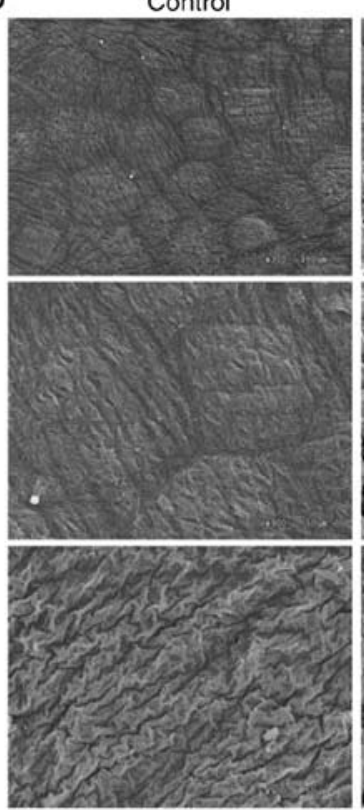
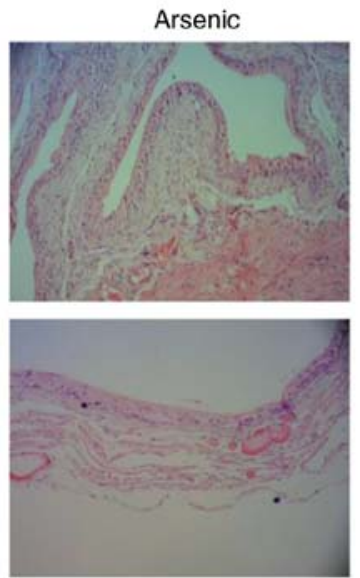

Arsenic
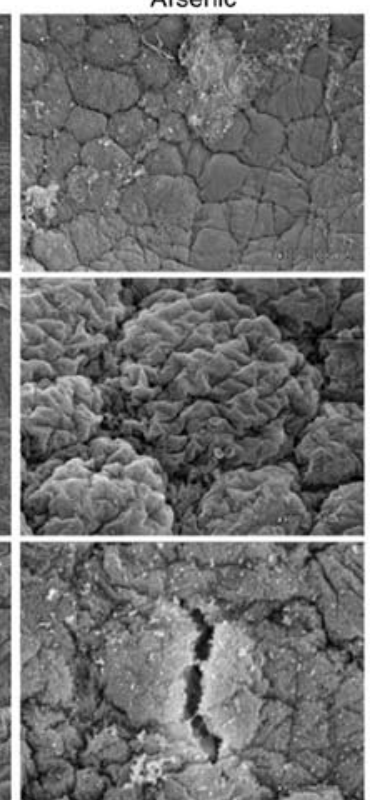

Figure 1 . The body weight change and bladder morphologic alternation of the mice. Mice were administrated 0 ppm $(\mathrm{Control}, \mathrm{n}=12)$ and $50 \mathrm{ppm}$ arsenic (Arsenic, $\mathrm{n}=12$ ) in drinking water, respectively, for 14 days. (A) They were weighed 1 day before Day 1 (Day 0 ), and Days 4, 7, 11 and 14 . The weight of Day 0 was set as $100 \%$. After euthanization, the bladders were harvested for H\&E staining and examined by light microscopy at a magnification of (B) x100 and (C) x400 magnification. Upper panels: Empty bladder (n=6 in each group), lower panels: Inflated bladder (n=6 in each group). Arrows: Intracellular inclusions. (D) The inflated bladders were also assessed by SEM at a magnification of x300 (upper images) and x900 magnification (middle and lower images). SEM, scanning electron microscopy.

(Fig. 1D, arsenic group). Certain surface leakages were also present in arsenic-treated mice (Fig. 1D). Furthermore, arsenic caused additional extensive hydropic degeneration of hepatocytes, characterized by diffuse vacuolated swelling of the hepatocytic cytoplasm and narrowed sinusoidal capillary spaces (Fig. S1).

Gene expression alterations of mouse bladder by sodium arsenite. Following 2 weeks of treatment, total RNA was isolated from bladder tissues derived from control and arsenic-treated mice by the mouse oligonucleotide DNA microarray chip. The results indicated 75 upregulated genes and 139 downregulated genes (Table SI). The data were deposited in the GEO database (accession no. GSE116554). In order to filter out gene expression related to DNA methylation, the DNA samples from one control and one arsenic-treated mouse were analyzed by MeDIP sequencing (Welgene
Biotech Co., Ltd.) to obtain preliminary data (data not shown). After integration analysis of DNA microarray data, MeDIP sequencing data, PubMed literature screening, and DNA CpG island searching, 4 cancer-related genes (Table I) containing potential CpG island regions (Fig. S2) were selected for RNA expression verification. CBS, a main metabolic enzyme which synthesizes $\mathrm{H}_{2} \mathrm{~S}$, was revealed to be upregulated in bladder cancer (25), and its DNA hypomethylation has been revealed to be correlated with the tumor stage in colorectal cancer (26). MALAT1 is a long noncoding RNA, which promotes cancer cell proliferation, metastasis and invasion in several tumor types including bladder cancer and cholangiocarcinoma $(27,28)$. ADORA1 is a type of adenosine receptor that is overexpressed in breast cancer (29). An ADORA1 antagonist was reported to induce MCF-7 cell apoptosis (30). WIF1 is one of the secreted frizzled-related protein antagonists that is downregulated in several types of cancer (31). Hypermethylation of WIF1 DNA 
Table I. Normalized intensities of Cbs, Malat1, Adoral and Wifl gene in control and arsenic-treated mouse bladder from DNA microarray chip analysis.

\begin{tabular}{lcccr}
\hline & \multicolumn{2}{c}{ Normalized Intensity } & & \\
\cline { 2 - 3 } Gene (ID) & Control & Arsenic & $\log _{2}$ (arsenic/control) & P-value \\
\hline Cbs (12411) & 120 & 252 & 1.147 & 0.00674 \\
Malat1 (72289) & 3982 & 9069 & 1.065 & 0.00208 \\
Adoral (11539) & 276 & 451 & 0.690 & 0.01485 \\
Wifl (24117) & 853 & 472 & -0.925 & 0.00079 \\
\hline
\end{tabular}

Cbs, cystathionine $\beta$-synthase; Malat1, metastasis-associated lung adenocarcinoma transcript 1; Adoral, adenosine A1 receptor; Wifl, Wnt inhibitory factor 1 .

has also been reported in bladder cancer (32), chondrosarcoma (33), and non-small cell lung cancer (34). Quantitative real-time PCR was applied for RNA detection of these 4 genes including 3 upregulated (Cbs, Malat1, Adoral) genes and 1 downregulated gene (Wifl). The results indicated that the mRNA expression levels of the $C b s$ and Adoral genes were significantly increased by arsenic treatment. The expression levels of Malat1 were also increased, however the results did not reveal a significant difference. In contrast to these observations, the expression levels of Wifl were slightly decreased, and no significant difference was obtained between the control and arsenic-treated mice (Fig. 2A).

Sodium arsenite did not alter the CpG island methylation ratio of $\mathrm{Cbs}$ and Adoral genes in mouse bladder tissues. DNA CpG methylation is one of the main mechanisms required for gene regulation. The presence of the $\mathrm{CpG}$ island near the transcription start site (TSS) of $C b s$ and Adoral genes was used for DNA methylation analysis. The $\mathrm{CpG}$ island methylation levels of $\mathrm{Cbs}$ and Adoral were estimated to 1.40 and $0.31 \%$, respectively in control mouse bladder tissues. Following arsenic treatment, the methylation levels noted in $\mathrm{Cbs}$ and Adoral were 1.05 and $0.78 \%$, respectively (Fig. 2B and C). The methylation levels of $\mathrm{Cbs}$ and Adoral were very low $(<2 \%)$ in control mice, indicating that these genes were not silenced by $\mathrm{CpG}$ island methylation under normal conditions. Therefore, the gene activation of $\mathrm{Cbs}$ and Adoral by arsenic may be mediated by specific transcription factors, translational activation and/or inhibition of RNA degradation.

Effects of arsenic on gene expression regulation of $C B S$, ADORA1, MALAT1 and WIF1 in the human normal urinary epithelial cell line $S V$-HUC-1. In addition to the animal studies, the effects of arsenic on the four selected genes were also analyzed in normal human urothelial SV-HUC-1 cells. Following arsenic treatment for 14 days, the mRNA expression levels of WIF1 were altered (Fig. 3A). However, the mRNA expression levels of ADORA1, CBS and MALAT1 (Fig. 3A) were not altered. Arsenic treatment decreased WIFI mRNA and protein expression (Fig. 3A and B). The effects of arsenic on WIFl gene methylation were further analyzed in SV-HUC-1 cells. Following 14-day treatment by $0.5 \mu \mathrm{M}$ of sodium arsenite, the genomic DNA was extracted for bisulfite conversion and DNA methylation analysis. Using BSP-MSP/USP analysis, the data indicated that arsenic slightly increased the MSP ratio (Fig. 3C). This indicated that the decrease in the levels of WIFl expression caused by arsenic may be partly mediated by the increase in the DNA methylation levels. In order to confirm this hypothesis, the cells were treated with $0.5 \mu \mathrm{M}$ sodium arsenite for 10 weeks. The results indicated that WIFl mRNA levels were further decreased (Fig. 3D) and that the MSP ratio was considerably increased (Fig. 3E). The inverse correlation between MSP ratio and WIF $1 \mathrm{mRNA}$ expression was also reported in bladder tumor samples from primary transitional cell carcinoma patients (32).

Effects of arsenic on cellular functions in the human normal urinary epithelial cell line SV-HUC-1. Cell proliferative activity was analyzed to assess arsenic-induced urothelial hyperplasia in mice. Arsenic caused a decrease in cell proliferation (Fig. 4A and B). The migratory activity was further analyzed by Transwell assay. Following a 14-day and 10-week treatment with arsenic of the cells, the migratory ability of the urothelial cells was slightly (14-day, Fig. 4C) and significantly (10-week, Fig. 4D) increased. This indicated that sodium arsenite promoted urothelial migration following long-term treatment, although it was capable of inhibiting cell proliferation.

Gene expression profile and DNA CpG methylation analysis of the WIFl gene in various human urinary epithelial cell lines. The mRNA expression and the DNA methylation levels of WIFl were assayed in various human urothelial cell lines in order to examine the differential expression of this gene in normal and cancer tissues. The 7 urothelial carcinoma cell lines, namely 5637, J82, RT4, 1376, T24, TSGH8301 and BFTC905 expressed lower levels of WIF1 mRNA (Fig. 5A) compared with those observed in the normal urothelial cell line SV-HUC-1. In addition, these cell lines expressed higher levels of DNA MSP ratio, with the exception of 5637, compared with the corresponding normal cell line (Fig. 5B). The DNA methyltransferase inhibitor 5-aza-2'-deoxycytidine increased WIF1 expression in 5 bladder cancer cell lines (Fig. 5C), indicating that WIFl gene expression was inhibited in urothelial carcinoma cells, possibly as a result of DNA CpG methylation. 
A

Cbs

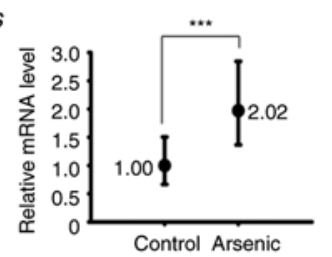

Adora1

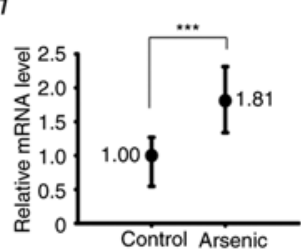
Control Arsenic

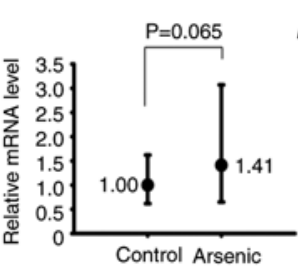

Malat1

B

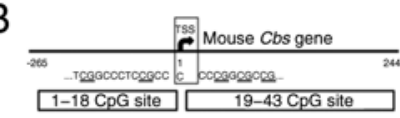
Control mouse 1 (1000000000000000000 0000000000000000000000000 20000000000000000000000000000000000000000000 40000000000000000000000000100000000000000 50000000000000000000000000000000000000000000000

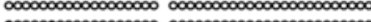
(1) 10 Control mouse 2

10000000000000000000000000000000000000000000

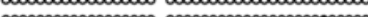
,

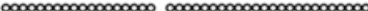
0000000000000000000000000000000000000000000 , 0000000000000000000000000000000000000000000 ए

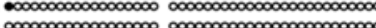

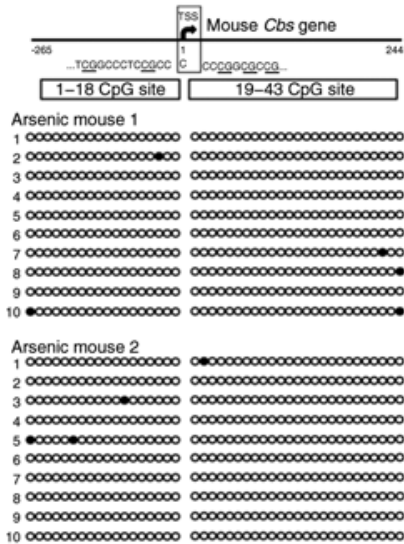

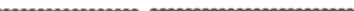

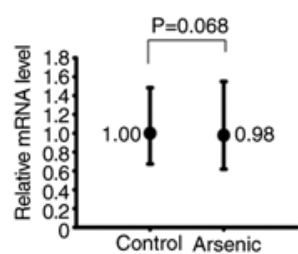
Control Arsenic
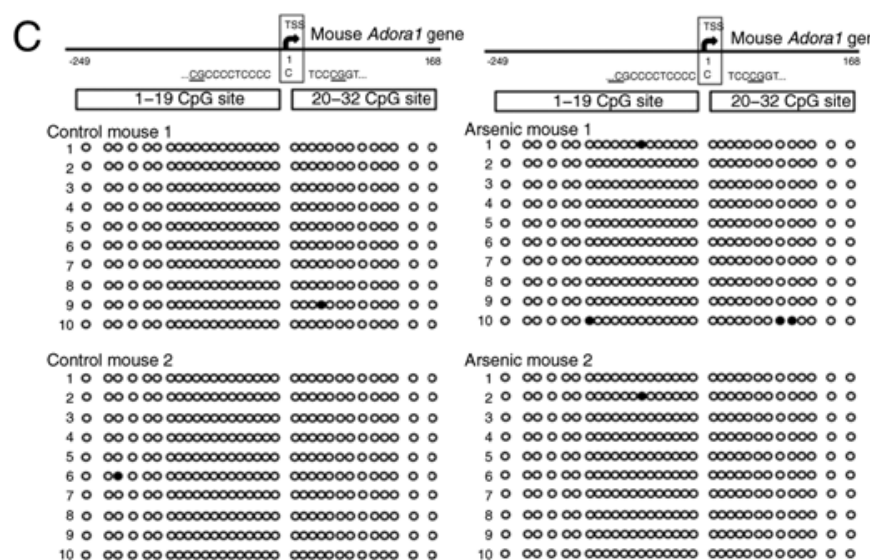

Figure 2. The relative mRNA expression and DNA CpG methylation level of selected genes in the mouse bladders. Mice were administrated 0 ppm (Control, $\mathrm{n}=6$ ) or $50 \mathrm{ppm}$ arsenic (Arsenic, $\mathrm{n}=6$ ) in drinking water for 14 days. (A) After euthanization, the RNA from the bladders was extracted and analyzed by RT-qPCR. ${ }^{* * *} \mathrm{P}<0.001$. (B and C) The DNA CpG methylation pattern of $\mathrm{Cbs}$ and Adoral genes in the mouse bladders. Mice were administrated 0 ppm (Control, $\mathrm{n}=2$ ) or $50 \mathrm{ppm}$ arsenic (Arsenic, $\mathrm{n}=2$ ) in drinking water for 14 days. After euthanization, the DNA from the bladders was extracted and analyzed by BSP assay. Circles represent a CpG site with methylation (closed circle) or without methylation (open circle) in the CpG island of (B) Cbs and (C) Adoral genes. Cbs, cystathionine $\beta$-synthase; Adoral, adenosine A1 receptor; RT-qPCR, reverse transcription-quantitative real-time PCR; BSP, bisulfite-sequencing PCR; Malat1, metastasis-associated lung adenocarcinoma transcript 1; Wifl, Wnt inhibitory factor 1.

\section{Discussion}

In the present study, it was demonstrated that arsenic increased the expression levels of mouse $C b s$ and Adoral regardless of the levels of DNA methylation, while it concomitantly decreased human WIFl expression partly by increasing DNA $\mathrm{CpG}$ methylation. The present data further suggested that the regulation of arsenic-induced gene expression was not the same between different species (mice vs. humans), which may have accounted for the differences noted in vivo and in vitro. It has been revealed that inorganic arsenic is metabolized to organic arsenic in specific organisms by multiple pathways including glutathione and methyl conjugation (35). However, these effects have not been revealed in cells derived from human bladder tissues (36). The data reported in the present study indicated that $50 \mathrm{ppm}$ arsenic $(666 \mu \mathrm{M}$ sodium arsenite) did not affect mouse body weight, although $0.5 \mu \mathrm{M}$ of sodium arsenite retarded cell proliferation in SV-HUC-1 cells. Therefore, in vivo, sodium arsenite may be metabolized to organic arsenic, which is less cytotoxic than the inorganic arsenic form noted in cultured cells (37). In our experience, the toxicity of $0.5 \mu \mathrm{M}$ sodium arsenite is similar to $100 \mu \mathrm{M}$ dimethyl arsenic acid in cultured bladder cells. Therefore, not only cytotoxicity, but also the biological response of arsenic metabolities (e.g. dimethyl arsenic) should be different from sodium arsenite.

Oral arsenic but not local treatment relates to a higher odds ratio of developing bladder, lung and liver cancers in human (9), and induces carcinogenesis of bladder, liver (37) and lung (38) in animal models. In the present study, short-time arsenic exposure only induced histological change but not tumor formation in the bladder and liver. In theory, there are multiple enzymes in liver cells for drug metabolism including inorganic arsenic, and liver damage may affect arsenic metabolism. Different arsenic metabolites may alter the response of arsenic in the bladder. Therefore, arsenic-induced liver damage may affect the toxicity of arsenic to the bladder. As for the lung, a limitation of the present study was that there was no histological examination on lung tissue.

KEGG Pathway analysis of this mouse gene expression data resulted 12 geneset pathways (Table SII). Although WNT signaling was not revealed in the results of the pathway analysis; however, Gene Ontology analysis concluded that WIF1 belongs to negative regulation of the WNT signaling 
A
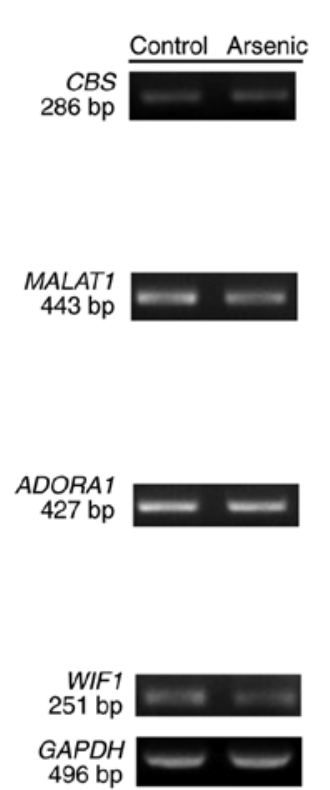

B

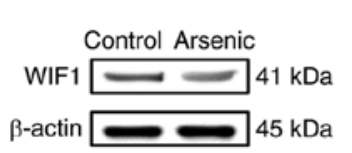

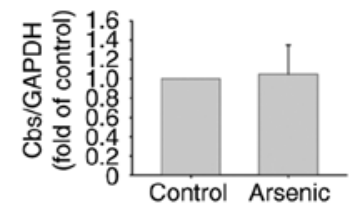
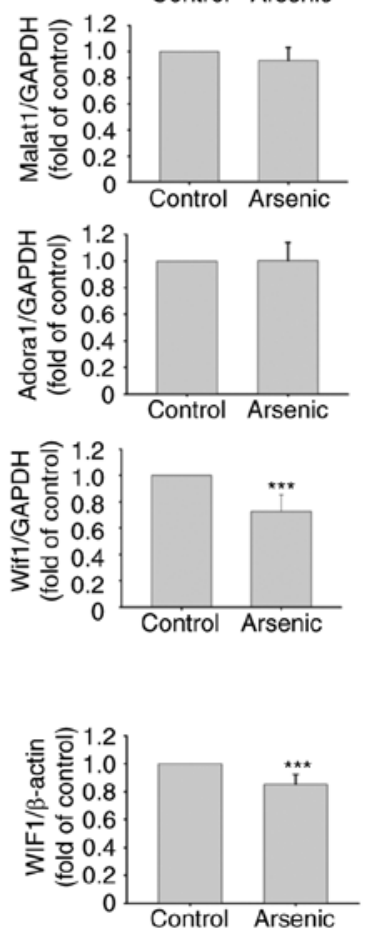

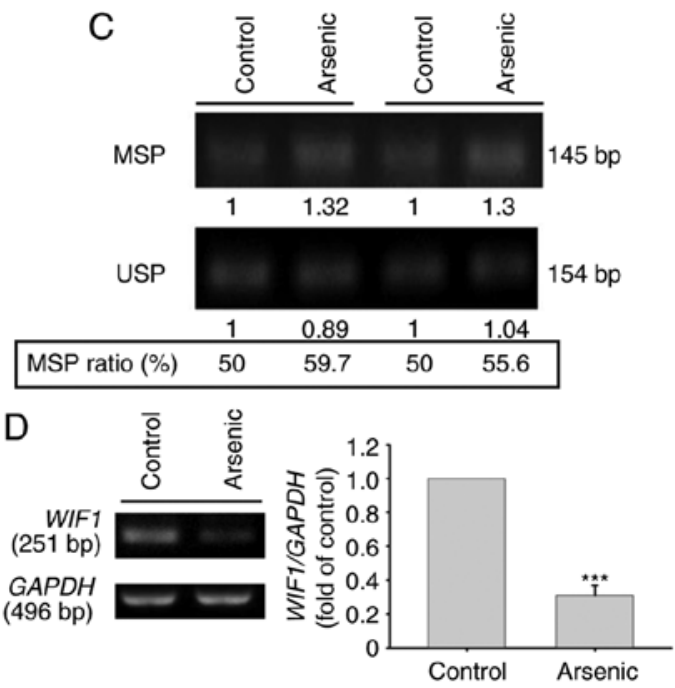

$\mathrm{E}$
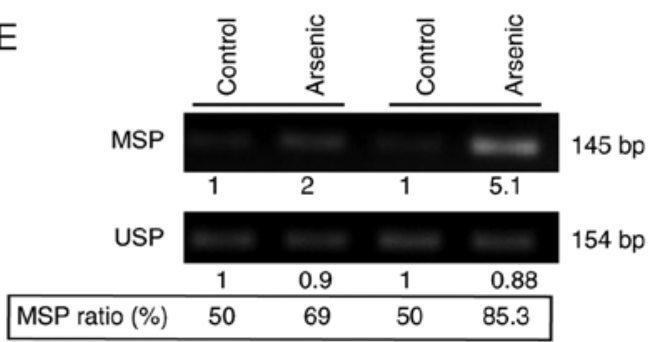

Figure 3. Gene expression and DNA CpG methylation analysis of selected genes in SV-HUC-1 cells. (A and B) Gene expression analysis. After $0.5 \mu \mathrm{M}$ sodium arsenite treatment for 14 days, RNA was extracted and analyzed by (A) RT-PCR, or protein was extracted and analyzed by (B) western blotting with anti-WIF1 antibodies. The quantified data of the histograms were calculated from seven (WIF1 mRNA) and four (WIF1 protein) independent experiments. ${ }^{* * *} \mathrm{P}<0.001$ compared to control. (C) DNA CpG methylation analysis of the WIF1 gene. After $0.5 \mu \mathrm{M}$ sodium arsenite treatment for 14 days, DNA CpG methylation was analyzed by BSP-MSP/USP assay. The MSP ratio=MSP intensity/MSP intensity + USP intensity. (D and E) Gene expression and DNA CpG methylation analysis of the WIF1 gene after $0.5 \mu \mathrm{M}$ sodium arsenite treatment for 10 weeks. (D) The mRNA expression level of WIF1 was analyzed by RT-PCR (n=3 from 3 independent experiments; ${ }^{* *} \mathrm{P}<0.001$ compared to control) and (E) DNA CpG methylation was analyzed by BSP-MSP/USP assay. WIF1, Wnt inhibitory factor 1; BSP, bisulfite-sequencing PCR; MSP, methylation-specific PCR; USP, unmethylation-specific PCR.

A

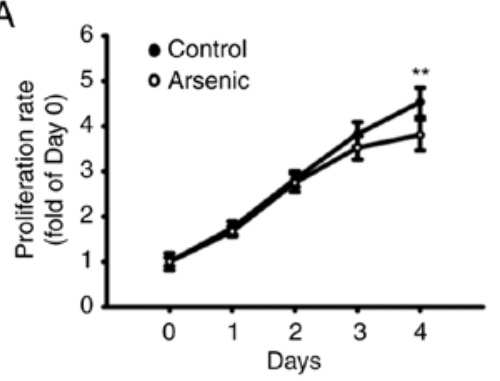

B

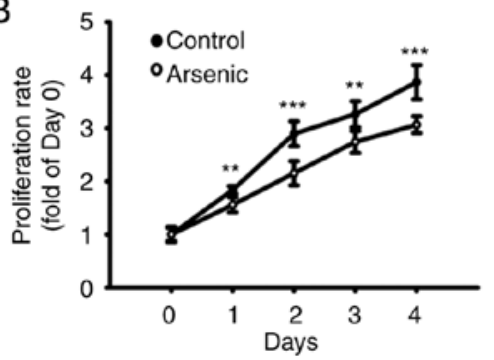

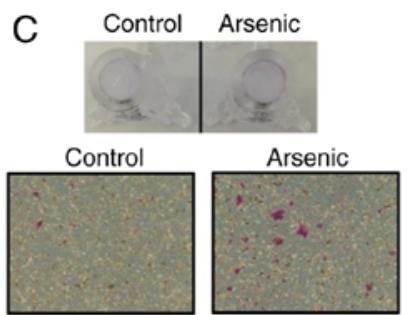
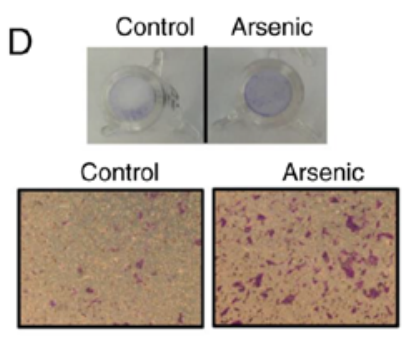
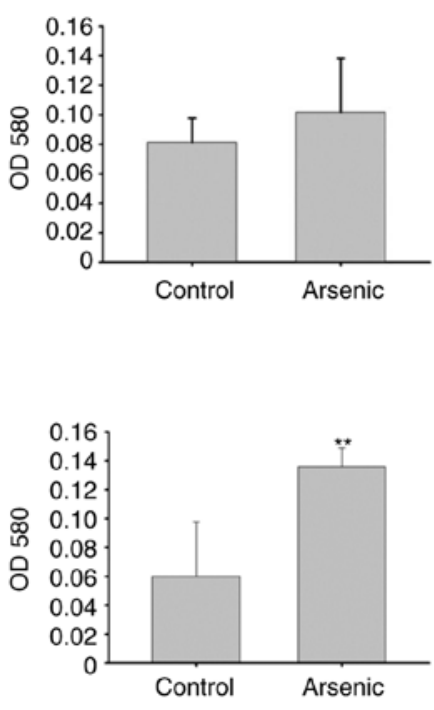

Figure 4. Effect of sodium arsenite on SV-HUC-1 cell proliferation and migration. (A and B) Effect of $0.5 \mu \mathrm{M}$ sodium arsenite on cell proliferation after (A) 14-day treatment ( $\mathrm{n}=12$ from 2 independent experiments) and (B) 10 -week ( $\mathrm{n}=12$ from 2 independent experiments) treatment. ${ }^{* *} \mathrm{P}<0.01,{ }^{* * *} \mathrm{P}<0.001$ compared to the control (among 2 samples in the same day). (C and D) Effect of $0.5 \mu \mathrm{M}$ sodium arsenite on cell migration after (C) 14-day and (D) 10-week treatment. The upper image is the eye-view of the insert, the lower image was obtained under a microscope, and the histogram was the OD580 values calculated from three inserts. ${ }^{* *} \mathrm{P}<0.01$, compared to control. 


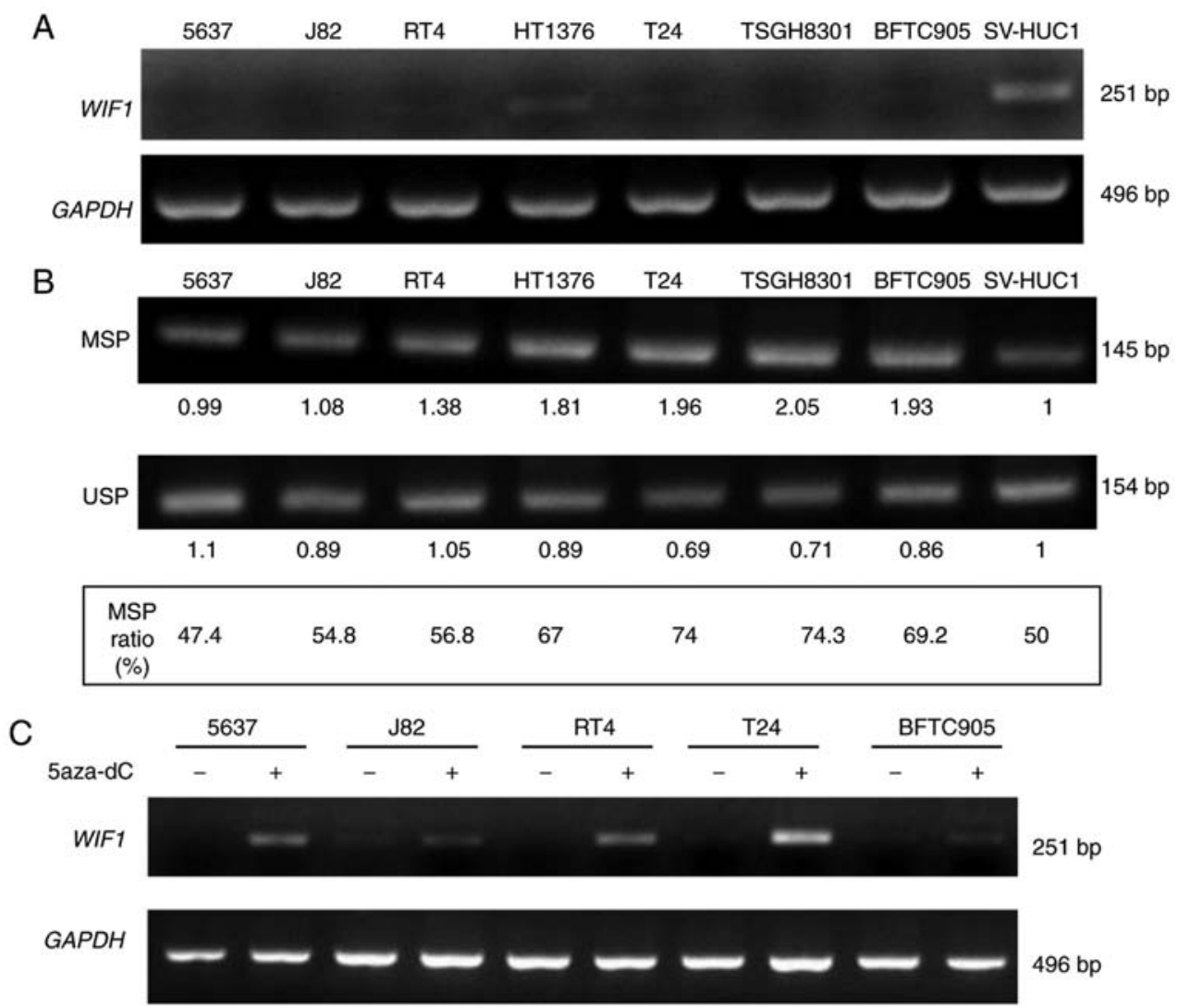

Figure 5. The RNA expression level and DNA CpG methylation level of WIFl in 8 human urothelial cell lines. (A) The mRNA expression level of WIFI was analyzed by RT-PCR assay. (B) The DNA methylation level of WIFl was analyzed by BSP-MSP/USP assay. The MSP ratio (\%)=MSP intensity/MSP intensity + USP intensity. Seven human bladder cancer cell lines (5637, J82, RT4, 1376, T24, TSGH8301, BFTC905) and one normal human urothelial cell line (SV-HUC1) were analyzed concurrently. (C) WIF1 mRNA expression after 5-aza-2'-deoxycytidine treatment for 3 days. WIF1, Wnt inhibitory factor 1; BSP, bisulfite-sequencing PCR; MSP, methylation-specific PCR; USP, unmethylation-specific PCR.
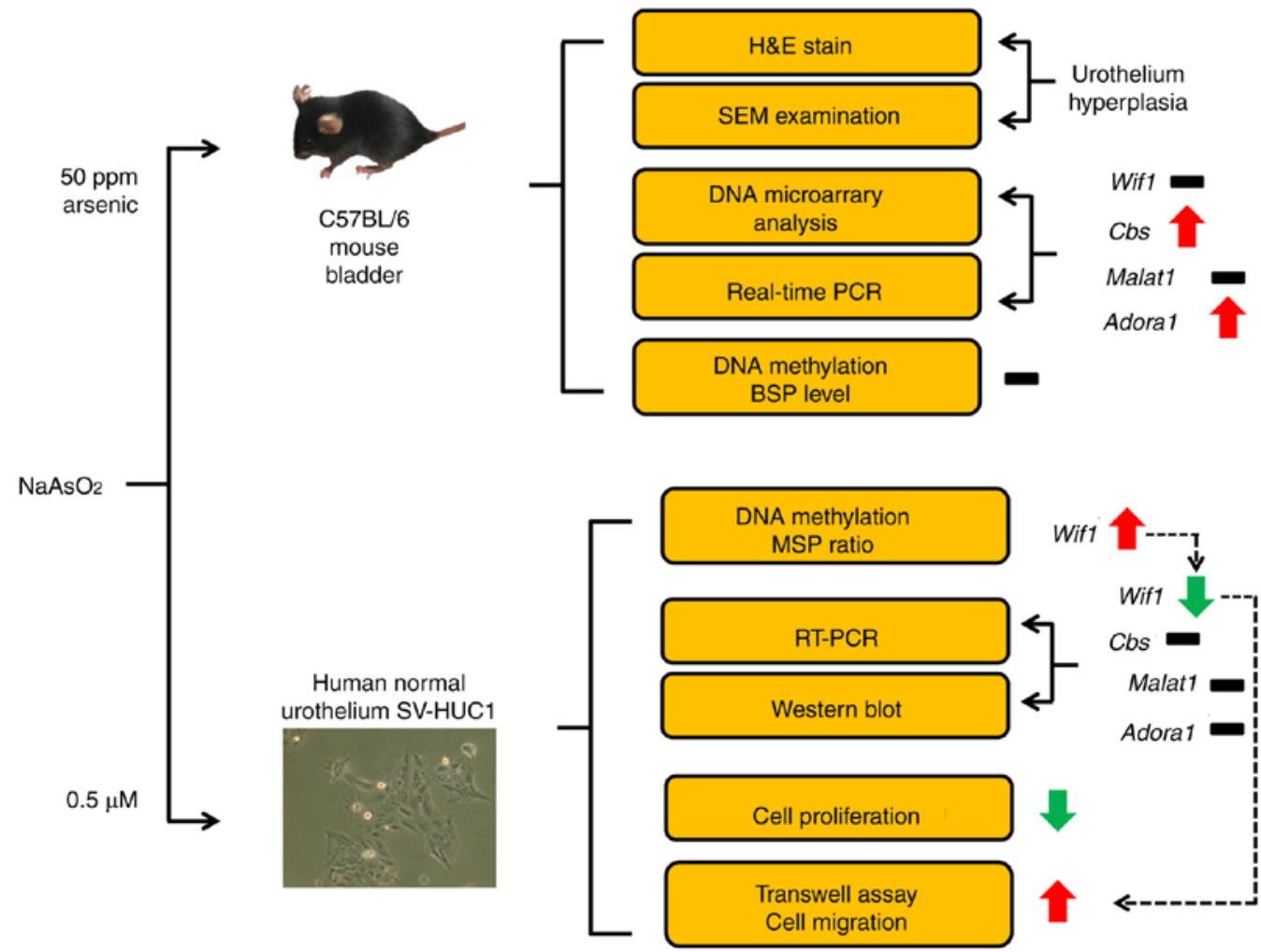

Figure 6. Schematic illustration of arsenic-induced gene regulation in mouse bladders and in human urothelium. Red arrow up indicates upregulation, green arrow down indicates downregulation, black minus indicates no change. 
pathway (GO:0030178). WIF1 is one of the functional inhibitors of the WNT pathway (39). The WNT signaling pathway is generally divided into 3 subpathways as follows: Canonical, non-canonical planar cell polarity (PCP), and non-canonical WNT/calcium (40). In the WNT-activated canonical pathway, $\beta$-catenin accumulates in the cytoplasm and translocates to the nucleus in order to cause activation of specific genes including the epithelial-mesenchymal transition (EMT)-related genes. The PCP pathway affects the cytoskeleton and triggers the expression of target genes responsible for cell adhesion and migration. In the calcium-dependent pathway, WNT further enhances cell migration by the activation of calmodulin. The WNT signaling complex originates from multiple membrane receptors, which are extracellularly regulated by various secreted antagonists, including Cerberus, Dickopf-related protein 1 (DKK1), secreted Frizzled-related protein (SFRP) and Sclerostin/Wise and Wnt inhibitory factor (WIF) (41). Among these WNT antagonists, SFRP (42) and WIFl (32) have been reported to possess lower mRNA expression levels and higher promoter methylation levels in bladder tumor samples than those noted in the corresponding normal tissues. In addition to bladder cancer, WIFl DNA hypermethylation has been identified as a potential biomarker for the diagnosis of lung cancer (32) and chondrosarcoma (33). Since WIF1 inhibits WNT-related cell migration, reduced WIF1 expression may be one of the mechanisms involved in arsenic-induced cell migration (Fig. 4C and D). By performing a search in the Oncomine database, it was demonstrated that the mRNA expression levels of WIFI exhibited a significant decrease in the infiltration of bladder urothelial carcinoma compared with that noted in superficial bladder cancer (Fig. S3). The data indicated that WIF1 downregulation was associated with bladder cancer progression.

CBS is the enzyme catalyzing the first step of the conversion of homocysteine to cysteine. In addition, it further catalyzes the metabolism of homocysteine and cysteine to cystathionine and hydrogen sulfide (43). In the present study, arsenic increased $C b s$ mRNA expression without altering its DNA methylation levels (Fig. 2A and B). The DNA methylation levels of $C b s$ were low in normal mouse bladder tissues (Fig. 2B), possibly due to the gene expression not being affected by DNA demethylation. ADORA1 is a membrane receptor expressed ubiquitously in the body. Similar to $\mathrm{Cbs}$, Adoral DNA methylation levels were also low in normal mouse bladder tissues (Fig. 2C). Therefore, the increase in the levels of Adoral was not mediated by DNA demethylation. The contribution of ADORAl in cancer progression remains controversial. For example, the application of ADORA1 antagonists in MCF-7 breast cancer cells induced cell apoptosis via the induction of p53 expression (30); however, in colorectal cancer, metformin induced apoptosis via the ADORA1/AMPK/mTOR pathway (44). In the present study, the expression levels of arsenic-induced $\mathrm{Cbs}$ and Adoral genes were upregulated in mouse bladder tissues and not in human urothelial cells. Using Oncomine search, the absence of differential expression in $C B S$ and ADORAl mRNA levels in bladder cancer tissues [bladder cancer database, threshold by: P-value (1E-4), fold change (1.5) and gene rank (all)] was demonstrated.

Animal experiments are an essential step prior to the conduct of clinical studies. The main species used in animal studies is rodents. Despite the extensive use of rodents in research, in some cases concerns are raised regarding the discrepancies between animal models and human population studies. For example, in the case of arsenic, it is not easy to induce cancer in rodents unless a high dosage of this compound is used (12). In contrast to these observations, several epidemiological studies have suggested that arsenic is a pivotal factor for the development of human cancer $(45,46)$. Our previous study demonstrated that $N$-butyl- $N$-(4-hydroxybutyl) nitrosamine (BBN) caused a decrease in glutathione $S$-transferase Mu1 (Gstm1) levels by downregulating the expression of the corresponding gene (47). However, the GSTM1 gene is deleted in approximately $50 \%$ of humans (48), whereas this percentage is not found in mice. The gene regulation of GSTM1 is different between mice and humans. Analysis of the gene expression changes of BBN-induced bladder cancer in mice and rats revealed that approximately $6 \%$ of genes shared the same regulation pattern in these two species (49). This indicated that the regulation of carcinogen-induced bladder cancer genes was distinct in mice and rats. Therefore, it may be assumed that these differences are also present between rodents and humans. In a similar study, it was revealed that $25 \mathrm{mg} / \mathrm{kg}$ of ketamine induced rat bladder inflammation and cyclooxygenase- 2 expression (50), whereas $100 \mathrm{mg} / \mathrm{kg}$ of ketamine did not cause significant inflammation in mouse bladder tissues (51). In the present study, we provide additional evidence that the gene regulation of $C B S, A D O R A I$ and WIFI was different between mouse bladder tissues and human urothelial cells. Therefore, the extrapolation of rodent to human data should be assessed with caution.

In summary (Fig. 6), the present study demonstrated that sodium arsenite induced gene expression alteration, hyperplasia and dysplasia in mouse urothelium. Arsenite increased $\mathrm{Cbs}$ and Adoral gene expression without affecting DNA methylation levels in the mouse bladder. In contrast to these two genes, sodium arsenite reduced WIF1 gene expression in human urothelium, and increased its DNA methylation levels, which may play a role in the gene downregulation. In addition, the downregulation of the WIFl gene may increase cell migration. Finally, the decrease in gene expression and the increase in DNA methylation of WIFI could be considered potential biomarkers for the diagnosis of human bladder cancer.

\section{Acknowledgements}

Not applicable.

\section{Funding}

The present study was supported by grants from the Ministry of Science and Technology of the Republic of China, Taiwan MOST 107-2320-B-415-001 and from Ditmanson Medical Foundation Chiayi Christian Hospital Research Program R107-002, Taiwan.

\section{Availability of data and materials}

The datasets used and/or analyzed during the current study are available from the corresponding author upon reasonable request. 


\section{Authors' contributions}

YCJ, SCW, and YWL were involved in the design of the study, acquisition, and interpretation of data and drafting the article. SCW and SYC performed the experiments. YCD and CHS assisted histopathologic analysis. YCJ and YWL analyzed and discussed the data. YRL and LCC assisted in the statistical analysis and interpretation of the data and revised the article. All authors read and approved the manuscript and agree to be accountable for all aspects of the research in ensuring that the accuracy or integrity of any part of the work are appropriately investigated and resolved.

\section{Ethics approval and consent to participate}

All animal experiments were performed according to the national and institutional guidelines and were approved by the Institutional Animal Care and Use Committee of National Chiayi University (approval no. 103040.1) authorized by the local government for the regulation of animal welfare.

\section{Patient consent for publication}

Not applicable.

\section{Competing interests}

The authors declare that they have no competing interests.

\section{References}

1. Hughes MF: Arsenic toxicity and potential mechanisms of action. Toxicol Lett 133: 1-16, 2002.

2. IARC: Arsenic and inorganic arsenic compounds (http://monographs.iarc.fr/ENG/Classification/latest_classif.php). World Health Organization 1-121: 41-94, 2012.

3. Lee-Feldstein A: Cumulative exposure to arsenic and its relationship to respiratory cancer among copper smelter employees. J Occup Med 28: 296-302, 1986.

4. Tseng WP: Effects and dose-response relationships of skin cancer and blackfoot disease with arsenic. Environ Health Perspect 19 109-119, 1977.

5. Cebrian ME, Albores A, Aguilar M and Blakely E: Chronic arsenic poisoning in the north of Mexico. Hum Toxicol 2: 121-133, 1983.

6. Chiou HY, Chiou ST, Hsu YH, Chou YL, Tseng CH, Wei ML and Chen CJ: Incidence of transitional cell carcinoma and arsenic in drinking water: A follow-up study of 8,102 residents in an arseniasis-endemic area in northeastern Taiwan. Am J Epidemiol 153: 411-418, 2001.

7. Hopenhayn-Rich C, Biggs ML, Fuchs A, Bergoglio R, Tello EE Nicolli $\mathrm{H}$ and Smith $\mathrm{AH}$ : Bladder cancer mortality associated with arsenic in drinking water in Argentina. Epidemiology 7: $117-124,1996$.

8. Smith AH, Goycolea M, Haque R and Biggs ML: Marked increase in bladder and lung cancer mortality in a region of Northern Chile due to arsenic in drinking water. Am J Epidemiol 147: 660-669, 1998

9. Chen CJ, Chuang YC, You SL, Lin TM and Wu HY: A retrospective study on malignant neoplasms of bladder, lung and liver in blackfoot disease endemic area in Taiwan. Br J Cancer 53 399-405, 1986.

10. Tokar EJ, Benbrahim-Tallaa L, Ward JM, Lunn R, Sams RL II and Waalkes MP: Cancer in experimental animals exposed to arsenic and arsenic compounds. Crit Rev Toxicol 40: 912-927, 2010.

11. Wei M, Wanibuchi H, Morimura K, Iwai S, Yoshida K, Endo G Nakae D and Fukushima S: Carcinogenicity of dimethylarsinic acid in male F344 rats and genetic alterations in induced urinary bladder tumors. Carcinogenesis 23: 1387-1397, 2002.
12. Cohen SM, Ohnishi T, Arnold LL and Le XC: Arsenic-induced bladder cancer in an animal model. Toxicol Appl Pharmacol 222: 258-263, 2007.

13. Arnold LL, Eldan M, Nyska A, van Gemert M and Cohen SM: Dimethylarsinic acid: Results of chronic toxicity/oncogenicity studies in F344 rats and in B6C3F1 mice. Toxicology 223: 82-100, 2006

14. Yokohira M, Arnold LL, Pennington KL, Suzuki S, Kakiuchi-Kiyota S, Herbin-Davis K, Thomas DJ and Cohen SM: Effect of sodium arsenite dose administered in the drinking water on the urinary bladder epithelium of female arsenic $(+3$ oxidation state) methyltransferase knockout mice. Toxicol Sci 121: 257-266, 2011.

15. Arnold LL, Suzuki S, Yokohira M, Kakiuchi-Kiyota S, Pennington KL and Cohen SM: Time course of urothelial changes in rats and mice orally administered arsenite. Toxicol Pathol 42: 855-862, 2014.

16. Dai YC, Wang SC, Haque MM, Lin WH, Lin LC, Chen $\mathrm{CH}$ and Liu YW: The interaction of arsenic and N-butyl-N-(4-hydroxybutyl)nitrosamine on urothelial carcinogenesis in mice. PLoS One 12: e0186214, 2017.

17. Su PF, Hu YJ, Ho IC, Cheng YM and Lee TC: Distinct gene expression profiles in immortalized human urothelial cells exposed to inorganic arsenite and its methylated trivalent metabolites. Environ Health Perspect 114: 394-403, 2006.

18. Medeiros M, Zheng X, Novak P, Wnek SM, Chyan V, Escudero-Lourdes $\mathrm{C}$ and Gandolfi AJ: Global gene expression changes in human urothelial cells exposed to low-level monomethylarsonous acid. Toxicology 291: 102-112, 2012.

19. Boivin GP, Bottomley MA, Schimi PA, Goss L and Grobe N: Physiologic, behavioral, and histologic responses to various euthanasia methods in C57BL/6NTac male mice. J Am Assoc Lab Anim Sci 56: 69-78, 2017.

20. Leary S, Underwood W, Anthony R, Cartner S, Corey D, Grandin T, Greenacre C, Gwaltney-Brant S, MaCrackin MA, Meyer R, et al: AVMA guidelines for the euthanasia of animals: 2013 edition.

21. Kilkenny C, Browne W, Cuthill IC, Emerson M and Altman DG; National centre for the replacement refinement and reduction of animals in research: Animal research: Reporting in vivo experiments-the ARRIVE guidelines. J Cereb Blood Flow Metab 31: 991-993, 2011.

22. Weng L, Dai H, Zhan Y, He Y, Stepaniants SB and Bassett DE: Rosetta error model for gene expression analysis. Bioinformatics 22: 1111-1121, 2006.

23. Shen CH, Wang ST, Wang SC, Lin SM, Lin LC, Dia YC and Liu YW: Ketamine-induced bladder dysfunction is associated with extracellular matrix accumulation and impairment of clacium signaling in a mouse model. Mol Med Rep 19: 2716-2728, 2019

24. Dodmane PR, Arnold LL, Muirhead DE, Suzuki S, Yokohira M, Pennington KL, Dave BJ, Lu X, Le XC and Cohen SM: Characterization of intracellular inclusions in the urothelium of mice exposed to inorganic arsenic. Toxicol Sci 137: 36-46, 2014.

25. Gai JW, Qin W, Liu M, Wang HF, Zhang M, Li M, Zhou WH, Ma QT, Liu GM, Song WH, et al: Expression profile of hydrogen sulfide and its synthases correlates with tumor stage and grade in urothelial cell carcinoma of bladder. Urol Oncol 34: 166.e15-e20, 2016.

26. Xue G, Lu CJ, Pan SJ, Zhang YL, Miao H, Shan S, Zhu XT and Zhang Y: DNA hypomethylation of CBS promoter induced by folate deficiency is a potential noninvasive circulating biomarker for colorectal adenocarcinomas. Oncotarget 8: 51387-51401, 2017.

27. Li C, Cui Y, Liu LF, Ren WB, Li QQ, Zhou X, Li YL, Li Y, Bai XY and $\mathrm{Zu} \mathrm{XB}$ : High expression of long noncoding RNA MALAT1 indicates a poor prognosis and promotes clinical progression and metastasis in bladder cancer. Clin Genitourin Cancer 15: 570-576, 2017.

28. Wang C, Mao ZP, Wang L, Wu GH, Zhang FH, Wang DY and Shi JL: Long non-coding RNA MALAT1 promotes cholangiocarcinoma cell proliferation and invasion by activating PI3K/Akt pathway. Neoplasma 64: 725-731, 2017.

29. Mirza A, Basso A, Black S, Malkowski M, Kwee L, Pachter JA, Lachowicz JE, Wang Y and Liu S: RNA interference targeting of A1 receptor-overexpressing breast carcinoma cells leads to diminished rates of cell proliferation and induction of apoptosis. Cancer Biol Ther 4: 1355-1360, 2005.

30. Dastjerdi MN, Rarani MZ, Valiani A and Mahmoudieh M: The effect of adenosine A1 receptor agonist and antagonist on p53 and caspase 3, 8, and 9 expression and apoptosis rate in MCF-7 breast cancer cell line. Res Pharm Sci 11: 303-310, 2016. 
31. Wissmann C, Wild PJ, Kaiser S, Roepcke S, Stoehr R, Woenckhaus M, Kristiansen G, Hsieh JC, Hofstaedter F, Hartmann A, et al: WIF1, a component of the Wnt pathway, is down-regulated in prostate, breast, lung, and bladder cancer. J Pathol 201: 204-212, 2003.

32. Urakami S, Shiina H, Enokida H, Kawakami T, Tokizane T, Ogishima T, Tanaka Y, Li LC, Ribeiro-Filho LA, Terashima M, et al: Epigenetic inactivation of Wnt inhibitory factor-1 plays an important role in bladder cancer through aberrant canonical Wnt/beta-catenin signaling pathway. Clin Cancer Res 12: 383-391, 2006.

33. Liu P, Shen JK, Hornicek FJ, Liu F and Duan Z: Wnt inhibitory factor 1 (WIF1) methylation and its association with clinical prognosis in patients with chondrosarcoma. Sci Rep 7: 1580, 2017.

34. GuoH,Zhou S, Tan L, Wu X, Wu Zand Ran R: Clinicopathological significance of WIF1 hypermethylation in NSCLC, a meta-analysis and literature review. Oncotarget 8: 2550-2557, 2017.

35. Watanabe T and Hirano S: Metabolism of arsenic and its toxicological relevance. Arch Toxicol 87: 969-979, 2013.

36. Styblo M, Del Razo LM, Vega L, Germolec DR, LeCluyse EL, Hamilton GA, Reed W, Wang C, Cullen WR and Thomas DJ: Comparative toxicity of trivalent and pentavalent inorganic and methylated arsenicals in rat and human cells. Arch Toxicol 74 289-299, 2000

37. Wanibuchi H, Salim EI, Kinoshita A, Shen J, Wei M, Morimura K, Yoshida K, Kuroda K, Endo G and Fukushima S: Understanding arsenic carcinogenicity by the use of animal models. Toxicol Appl Pharmacol 198: 366-376, 2004.

38. Cui X, Wakai T, Shirai Y, Hatakeyama K and Hirano S: Chronic oral exposure to inorganic arsenate interferes with methylation status of p16INK4a and RASSF1A and induces lung cancer in A/J mice. Toxicol Sci 91: 372-381, 2006.

39. Kawano Y and Kypta R: Secreted antagonists of the Wnt signalling pathway. J Cell Sci 116: 2627-2634, 2003.

40. Duchartre Y, Kim YM and Kahn M: The Wnt signaling pathway in cancer. Crit Rev Oncol Hematol 99: 141-149, 2016.

41. Niehrs C: The complex world of WNT receptor signalling. Nat Rev Mol Cell Biol 13: 767-779, 2012.

42. Wang X, Wang H, Bu R, Fei X, Zhao C and Song Y: Methylation and aberrant expression of the Wnt antagonist secreted Frizzled-related protein 1 in bladder cancer. Oncol Lett 4: 334-338, 2012.
43. Jhee KH and Kruger WD: The role of cystathionine beta-synthase in homocysteine metabolism. Antioxid Redox Signal 7: 813-822, 2005.

44. Lan B, Zhang J, Zhang P, Zhang W, Yang S, Lu D, Li W and Dai Q: Metformin suppresses CRC growth by inducing apoptosis via ADORA1. Front Biosci (Landmark Ed) 22: 248-257, 2017.

45. Baris D, Waddell R, Beane Freeman LE, Schwenn M, Colt JS, Ayotte JD, Ward MH, Nuckols J, Schned A, Jackson B, et al: Elevated bladder cancer in northern New England: The role of drinking water and arsenic. J Natl Cancer Inst 108: pii: djw099, 2016.

46. Saint-Jacques N, Parker L, Brown P and Dummer TJ: Arsenic in drinking water and urinary tract cancers: A systematic review of 30 years of epidemiological evidence. Environ Health 13: 44, 2014.

47. Chuang JJ, Dai YC, Lin YL, Chen YY, Lin WH, Chan HL and Liu YW: Downregulation of glutathione S-transferase M1 protein in N-butyl-N-(4-hydroxybutyl)nitrosamine-induced mouse bladder carcinogenesis. Toxicol Appl Pharmacol 279: 322-330, 2014.

48. Engel LS, Taioli E, Pfeiffer R, Garcia-Closas M, Marcus PM, Lan Q, Boffetta P, Vineis P, Autrup H, Bell DA, et al: Pooled analysis and meta-analysis of glutathione S-transferase M1 and bladder cancer: A HuGE review. Am J Epidemiol 156: 95-109, 2002.

49. Williams PD, Lee JK and Theodorescu D: Molecular credentialing of rodent bladder carcinogenesis models. Neoplasia 10: 838-846, 2008.

50. Juan YS, Lee YL, Long CY, Wong JH, Jang MY, Lu JH, Wu WJ, Huang YS, Chang WC and Chuang SM: Translocation of NF- $\mathrm{kB}$ and expression of cyclooxygenase-2 are enhanced by ketamine-induced ulcerative cystitis in rat bladder. Am J Pathol 185: 2269-2285, 2015.

51. Shen $\mathrm{CH}$, Wang SC, Wang ST, Lin SM, Wu JD, Lin CT and Liu YW: Evaluation of urinary bladder fibrogenesis in a mouse model of long-term ketamine injection. Mol Med Rep 14: 1880-1890, 2016

This work is licensed under a Creative Commons Attribution-NonCommercial-NoDerivatives 4.0 International (CC BY-NC-ND 4.0) License. 